\title{
Arbitrage Price Theory (APT) and Karachi Stock Exchange (KSE)
}

\author{
Sulaiman D. Mohammad \\ Professor, Federal Urdu University of Arts, Science and Technology, Pakistan \\ E-mail: sulaiman1959@gmail.com \\ Syed Iqbal Hussain Naqvi \\ Lecturer, Department of Commerce \\ Federal Urdu University of Arts, Science and Technology, Pakistan \\ E-mail: Siqbal110@yahoo.com \\ Irfan Lal \\ Lecturer, Institute of Business \& Technology, Bizteck, Pakistan \\ E-mail: Irf_yoch@yahoo.com
}

Saba Zehra

Lecturer, Department of Commerce

Federal Urdu University of Arts, Science and Technology, Pakistan

E-mail: Sabazehra89@yahoo.com

$\begin{array}{lc}\text { Received: June 14, } 2011 & \text { Accepted: August 30, } 2011 \quad \text { Published: February 1, } 2012 \\ \text { doi:10.5539/ass.v8n2p253 } & \text { URL: http://dx.doi.org/10.5539/ass.v8n2p253 }\end{array}$

\begin{abstract}
The intention of this study is to analyze the variability of Arbitrage price theory (APT) in case of KSE. The data from Jan 1985 to Dec 2008 is monthly based has been considered and two econometric methodologies, Johanson co integration and Error correction model are used to checkout the validity of APT in this study. The conclusion of this study illustrates that Quasi money responds negatively with KSE 100 index return while IIP (industrial index of production), exchange rate, petroleum price, domestic interest responds negatively with KSE 100 index return. On the Contrary bullion price and inflation rate are insignificant regarding to KSE 100 index returns
\end{abstract}

Keywords: KSE-100Index, Arbitrage pricing theory, Co integration

\section{Introduction}

Primary theory of finance is mainly focused on trade-off between volatility on assets prices and their returns, which shows that if one portfolio is overestimated only when another choice of portfolio is provided more risk in subsequent ways. Contemporary, there are two theories of portfolio choices with reference to risk diversification is more dominant i.e CAPM (Capital Assets Price Model) and APT (Arbitrage Price Theory).

The APT model defines that the forecasted rate of return on assets depends on volatility to macroeconomics variables which points out that factor risk takes more significant in assets pricing (Gilles et.al 1990). APT is comparatively a moderate diverse technique to analysis the assets prices model. It may cover different non market variables which influence the assets prices. It bases on the one price law: "two assets which are the identical may not be sold at various prices. Advancement is the utility and its assumption which were using by CAPM model are not essential". (Elton et al. 2003).

CAPM model requires the limit on return preferences and distributions but in the APT model limits are not as such therefore no arbitrage opportunities and returns are normally followed the variables structure and no heterogeneous expectations. (Gilles \& Leroy, 1990). 
Ross (1976) designed the APT model in which it was assumed that the stock prices were influenced partially and uncorrelated with most of the macroeconomics variables and these variables are not multicolinear with each other. Establishing this reason the model is according to efficient market hypothesis and expected return of the model where each factor of the coefficient has a linear combination. The APT model indicates that return of assets is the linear function of different macroeconomic variables and the changes occur in these variables are represented by specific factor's coefficient.

APT defines that expected return on stock prices is composed on the capital gain plus the realization of risk premium (macroeconomics variables risk) during the course time. The study is used to point out the macroeconomics variables shocks effect on the KSE within the APT frame work. This specific evaluation of KSE 100 index stands on monthly data of eight fundamental macroeconomic indicators i.e. CPI, interest rate, bullion price, IPI, petroleum price, exchange rate and Quasi money .

KSE due to its size can be called a leading stock market in Pakistan. Initially KSE commenced with 50 index with course of time market expanded, and got the conversion into 100 index on November 1, 1991. Later in the year of $2001 \mathrm{KSE}$ crossed the 1770 points, similarly in 2005, due to robust and high growth the KSE index has arrived at 9989 points. It the month of March 2006 KSE 100 index skyrocketed to 11485 points. The KSE 100 index bases on capital weight index and comprising top 100 companies and the total market capitalization is approximately eighty six present.

The order of this research consists: literature review, data, econometric methodology, results and last section covers conclusion.

\section{Review of Literature}

Different researches were carried out to explore the impact of stock market on economic growth which concludes positive and significant association between GDP growth and stock exchange. Arbitrage Pricing Theory (APT) is chosen for this study. This was firstly applied by Chen, Roll and Ross (1986) taking U.S. economy into consideration and found positive relationship.

Shahbaz (2008) has found positive association applying ARDL between equity market development and GDP growth in Pakistan. Mohammad S.D et al, (2009) examined the relationship among macroeconomic variables and Karachi Stock Exchange, quarterly data was used and concluded that exchange reserve and exchange rate significantly affected by equity market.

Abdullah and Hayworth (1993) formulated New York equity market returns have direct associated with CPI, economic growth and M2, on the contrary negatively associated with fiscal deficit, current account deficit, and also short term and long term market interest rate.

With reference to Japanese stock market, Hamao (1988) has replicated a model which was propounded by Chen, et al (1986) he analyses the macroeconomics variables with equity market returns. He was of the opinion that stock returns are influenced effectively by the volatile in future forecasted inflation and unforeseen changes in interest rate.

Evaluating the APT model Brown, Maysami and Koh (2000) have examined the associations among Singapore equity market and macroeconomic variables (CPI, investment, exchange rate, money supply etc.) over a period of 7 years (1988 to 1995) and concluded significant direct association between equity returns and changes in Quasi money while inverse relationship among equity returns with volatility in inflation levels, term structure of interest rate and effective rate of exchange rate.

Otsuki (1990) has concluded that the effect of the Quasi money, IIP, petroleum price, exchange rates and market error term with reference to Japanese equity market and shows that macroeconomics variables risk premium are significantly associated with Japanese stock market.

Mahmood and Dinniah et.al (2009) have analyzed the causal relationship among the macroeconomics variables and equity market with reference to six Asian and Pacific region countries i.e. Japan, Australia, Korea, Malaysia, Thailand and Hong Kong. Monthly data (January 1993 to December 2002) equity market, exchange rate, CPI and IIP were the variables which were used in this study. The analysis was mainly focused on the long run and short run equilibrium of equity prices and macroeconomics variables. The results conclude that long run equilibrium among equity market indices and other chosen variables is found only in 4 countries are Japan, Australia Korea, and Hong Kong further verify short run association in only three countries are Malaysia, Japan and Australia while, Thai equity market and Hong Kong equity market point out interactions at some extent. 
Bailey et.al (1996), have analyzed the shock of macroeconomic variables on the stock exchange with extent to Philippine equity market, indicate financial market shocks, exchange rate volatility and unstable political scenario could not be explained by Philippine stock returns due to some reasons.

\section{Data Source and Econometrics methodology}

Data derived from WDI (world development indicator), International Financial Statistics (IFS) from IMF and various publications of State Bank of Pakistan and monthly data was processed from January 1985 to December 2008.

\subsection{Research Model}

The main model of study is

\section{Dependent Variable:}

$$
K S E=\alpha+\beta_{1} C P I_{t}+\beta_{2} E X+\beta_{3} r+\beta_{4} I P P+\beta_{5} G P+\beta_{6} M 2+\beta_{7} G R+\beta_{8} O P+\varepsilon_{t}
$$

KSE is the proxy of KSE-100 Index returns that mention the Pakistan stock market performance

Independent variables:

Gold reserve (GR), Bullion price (GP), international petroleum price (OP), Exchange rate (EX), Industrial Index of Production (IIP), Quasi Money (M2), Money market rate (r) and Consumer price index (CPI)

\subsection{Econometrics methodology}

ADF (Augmented Dickey Fuller) test is one of the most reliable tests to check the unit root (trend pattern) in data or variables. The equation of unit root test is as follows:

Where, $\mu_{t}$ is a pure white noise error term where

$$
\Delta Y_{t}=\alpha+\beta Y_{t-1}+t+\sum \beta_{2} \Delta Y_{t-k}+\mu_{t}
$$

$$
\Delta y_{t-1}=\left(y_{t-1}-y_{t-2}\right), \Delta y_{t-2}=\left(y_{t-2}-y_{t-3}\right)
$$

In the above equation the study checkout the hypothesis that the value of beta is statistically significant or not. In 1979 Fuller formulated the cumulative distribution value of $t$ statistics; if the value of beta coefficient $t$ statistics above the tabulated value, it is the sign that time series data is stationary.

Johansen co integration technique was reliable and credible technique to analysis the long run association among the macroeconomics variables and stock prices. The traditional approach of Engle and Granger is non appropriate in case of multivariate equation. Another reason to use the $\mathrm{JJ}$ technique is that all the variables are stationary at same order integration. If variables are not integrated at different level or order, in this case the ARDL (Autoregressive Distribution Lag) model is used. In this study the variables are integrated at same level so JJ technique is much reliable to check long run association among the variables. If the co integration (long run relationship) exists than the movements towards the short run dynamics takes place. The generalized form of Error Correction Mechanism is as follows:

ECM equation of this research as:

$$
\begin{aligned}
& \Delta y_{t}=\beta_{\circ}+\beta_{1} y_{t-1}+\beta_{2} x_{t-1}+\sum_{j=1}^{q-1} \beta y_{, j} \Delta y_{t-j}+\sum_{j=1}^{q-1} \beta x,{ }_{j} \Delta y_{t-j}+\Delta x_{t}+\mu_{t} \\
& \text { of this research as: }
\end{aligned}
$$

$$
\begin{aligned}
& \triangle K S E=\alpha+\beta_{1} \Delta C P I{ }_{t}+\beta_{2} \Delta E X+\beta_{3} \Delta r+\beta_{4} \Delta I P P+\beta_{5} \Delta G P+\beta_{6} \Delta M 2+\beta_{7} \Delta G R+ \\
& \beta_{8} \Delta O P+\beta_{9} \mu_{t-1}+\varepsilon_{t}
\end{aligned}
$$

$\mathrm{B} 9=$ co integration equation has a connection with speed of adjustment

Coefficients of ECM mechanism explain short run performance of dependent variable and speed of adjustment explains the time period of recovery.

\section{Empirical Result}

ADF-Test along with trend and intercept are applied because it captures serial correlation problem, which is more credible. Selected macroeconomics variables and stock prices are significant at 5 percent level. Lag of macroeconomics variables and stock prices are according to AIC (Akaike Information Criteria) and SBC (Schwartz Bayesian Criteria).

$<$ Insert Table 1 here> 
Most of the Social sciences variables have time series trends and normally they have found stationarity at first or second difference. In this study, variables are integrated at first difference. Table no.1 shows that all the variables are integrated at first difference at $5 \%$ significant level lag selection (2) according to AIC.

$\mathrm{JJ}$ technique is used in this study because of the variables are fulfilling the requirement of said technique. The result of $\mathrm{JJ}$ technique is as follows.

$<$ Insert Table 2 and Table 3 here $>$

Table 2 and Table 3 highlighted the values of trace statistics and Eigen statistics confirm that the results are long run co-integrated which show the association among the stock prices and macroeconomics variables. Further it confirms that there are 3 long run co-integrated equations in vector. Maximum lag order is 2 by using (AIC), confirming co-integration therefore chosen variables forwarded to test the short run behavior and speed of adjustment.

Equation of error correction model

$$
\begin{aligned}
& \triangle K S E=\alpha+\beta_{1} \Delta C P I{ }_{t}+\beta_{2} \Delta E X+\beta_{3} \Delta r+\beta_{4} \Delta I P P+\beta_{5} \Delta G P+\beta_{6} \Delta M 2+\beta_{7} \Delta G R+ \\
& \beta_{8} \Delta O P+\beta_{9} \mu_{t-1}+\varepsilon_{t}
\end{aligned}
$$

$<$ Insert Table 4 here $>$

Table 4 shows the result of ECM (Error Correction Mechanism) its lag value of adjustment coefficient is negative and highly significant, ECM indicates a slow process of adjustment. ECM result pointed out $5 \%$ of disequilibrium which is adjusted within current period of time when the shock is occurred.

\section{Conclusions}

Pakistan's economy was taken to examine APT and its efficiency and found that a set of macroeconomic variables systematically influence with equity market returns. Empirical results of this study have shown that Gold price, Gold reserve, international crude and oil price positively related and significant with stock returns, on the other hand Industrial production index, Exchange rate, money market interest rate and Money supply are negatively related and significant with stock returns. It is also found that Pakistan's economy is consumption oriented and excess capacity in financial market is available.

\section{References}

Abdullah, A. Dewan \& Haywoth, C. Steven. (1993). Macroeconomics of Stock Price Fluctuations. Quarterly Journal of Business and Economics, 32(1), pp. 49-63.

Barrows, W. Clayton \& Naka Atsuyuki. (1994). Use of Macroeconomic Variables to Evaluate Selected Hospitality Stock Returns in the U.S.. International Journal of Hospitality Management, 13(2), pp. 119-128. http://dx.doi.org/10.1016/0278-4319(94)90033-7

Clare, D. Andrew \& Stephen H. Thomas. (1994). Macroeconomic Factors, the APT and the Economic Survey of Pakistan, 2008-09.

Gibbons, Michael R. (1982). Multivariate Tests of Financial Models. Journal of Financial Economics, 10(1), pp. 3-27. http://dx.doi.org/10.1016/0304-405X(82)90028-9

Huberman, Gur. (1982). A Simple Approach to Arbitrage Pricing Theory. Journal of Economic Theory, 28(1), pp. 183-191. http://dx.doi.org/10.1016/0022-0531(82)90098-9

Johansen, S. (1988). Statistical Analysis of Cointegration Vectors. Journal of Economic Dynamics and Control, pp: 231-54. http://dx.doi.org/10.1016/0165-1889(88)90041-3

MacKinlay, A. Craig. (1987). On Multivariate Tests of the CAPM. Journal of Financial Economics, 18(2), pp. 341-371. http://dx.doi.org/10.1016/0304-405X(87)90044-4

Mohammad, D. Suliaman, Hussain, Adnan \& Ali, Adnan. (2009). Impact of Macroeconomics Variables on Stock Prices: Empirical Evidence in Case of KSE (Karachi Stock Exchange). European Journal of Scientific Research, 38(1), pp. 96-103.

Muhammad Shahbaz. (2008). Stock Market Development and Economic Growth: Ardl Causality in Pakistan. International Research Journal of Finance and Economics, Issue 14.

Perron, P. (1989). The Great Crash, the Oil Price Shock and the Unit Root Hypothesis. Econometrica, pp: 1361-1401. http://dx.doi.org/10.2307/1913712 
UK Stock Market. Journal of Business Finance and Accounting, 21, pp. $309-330$. http://dx.doi.org/10.1111/j.1468-5957.1994.tb00322.x

Table 1. Augmented Dickey Fuller Unit root test

\begin{tabular}{|c|c|c|}
\hline Variable & Level with trend and intercept & $\begin{array}{c}\text { First difference with trend and } \\
\text { intercept }\end{array}$ \\
\hline KSE & 1.523 & $12.855^{*}$ \\
\hline CPI & 1.523 & $7.840^{*}$ \\
\hline EXR & 0.209 & $15.796^{*}$ \\
\hline R & 1.290 & $8.457^{*}$ \\
\hline IP & 0.079 & $6.176^{*}$ \\
\hline GP & 1.054 & $12.450^{*}$ \\
\hline M2 & 0.896 & $7.377^{*}$ \\
\hline GR & 1.829 & $15.873^{*}$ \\
\hline OP & 1.434 & $7.452^{*}$ \\
\hline
\end{tabular}

Significant at 5\% level, Lag selection (2)

Table 2. Johnsen co integration test (Maximum trace value)

\begin{tabular}{|c|c|c|c|c|}
\hline Null Hypothesis & $\begin{array}{l}\text { Alternative } \\
\text { Hypothesis }\end{array}$ & $\begin{array}{c}\text { Maximum trace } \\
\text { statistics }\end{array}$ & $5 \%$ critical value & Probability \\
\hline Ho $\mathrm{R}=0, \mathrm{H} 1 \mathrm{R}=1$ & 0.245891 & $261.5647^{*}$ & 197.3709 & 0.0000 \\
\hline Ho R $>1$, H1 R=2 & 0.210230 & $196.0900 *$ & 159.5297 & 0.0001 \\
\hline Ho $\mathrm{R}>2, \mathrm{H} 1 \mathrm{R}=3$ & 0.192339 & $141.3349 *$ & 125.6154 & 0.0039 \\
\hline Ho $\mathrm{R}>3, \mathrm{H} 1 \mathrm{R}=4$ & 0.118518 & 91.77663 & 95.75366 & 0.0910 \\
\hline Ho $\mathrm{R}>4, \mathrm{H} 1 \mathrm{R}=5$ & 0.100691 & 62.50978 & 69.81889 & 0.1665 \\
\hline Ho $\mathrm{R}>5, \mathrm{H} 1 \mathrm{R}=6$ & 0.084603 & 37.88789 & 47.85613 & 0.3069 \\
\hline Ho $\mathrm{R}>6, \mathrm{H} 1 \mathrm{R}=7$ & 0.044959 & 17.37961 & 29.79707 & 0.6120 \\
\hline Ho $\mathrm{R}>7, \mathrm{H} 1 \mathrm{R}=8$ & 0.027421 & 6.707400 & 15.49471 & 0.6119 \\
\hline Ho $\mathrm{R}>8, \mathrm{H} 1 \mathrm{R}=9$ & 0.001107 & 0.256928 & 3.841466 & 0.6122 \\
\hline
\end{tabular}

*significant at 5\% level 
Table 3. Johnsen co integration test (Maximum Eigen statistics)

\begin{tabular}{|c|c|c|c|c|}
\hline Null Hypothesis & $\begin{array}{l}\text { Alternative } \\
\text { Hypothesis }\end{array}$ & $\begin{array}{l}\text { Maximum Eigen } \\
\text { statistics }\end{array}$ & $5 \%$ critical value & Probability \\
\hline Ho $\mathrm{R}=0$, H1 R=1 & 0.245891 & 65.47472 & 58.43354 & 0.0088 \\
\hline Ho $\mathrm{R}>1$, H1 R=2 & 0.210230 & 54.75514 & 52.36261 & 0.0279 \\
\hline Ho R>2, H1 R=3 & 0.192339 & 49.55824 & 46.23142 & 0.0213 \\
\hline Ho $\mathrm{R}>3, \mathrm{H} 1 \mathrm{R}=4$ & 0.118518 & 29.26685 & 40.07757 & 0.4730 \\
\hline Ho $\mathrm{R}>4, \mathrm{H} 1 \mathrm{R}=5$ & 0.100691 & 24.62189 & 33.87687 & 0.4110 \\
\hline Ho $\mathrm{R}>5, \mathrm{H} 1 \mathrm{R}=6$ & 0.084603 & 20.50828 & 27.58434 & 0.3070 \\
\hline Ho $\mathrm{R}>6, \mathrm{H} 1 \mathrm{R}=7$ & 0.044959 & 10.67221 & 21.13162 & 0.6799 \\
\hline Ho R $>7$, H1 R=8 & 0.027421 & 6.450472 & 14.26460 & 0.5561 \\
\hline Ho $\mathrm{R}>8, \mathrm{H} 1 \mathrm{R}=9$ & 0.001107 & 0.256928 & 3.841466 & 0.6122 \\
\hline
\end{tabular}

*significant at 5\% level, Lag selection (2)

Table 4. Error Correction Model: Dependent variable D(KSE-100index)

\begin{tabular}{|l|l|l|l|}
\hline Variable & Coefficient & Standard error & t value \\
\hline$\Delta \mathrm{CPI}$ & 0.029070 & 0.722821 & 0.040218 \\
\hline$\Delta \mathrm{EXR}$ & -0.560121 & 0.855046 & -0.655077 \\
\hline$\Delta \mathrm{R}$ & -0.575515 & 0.223880 & -2.570643 \\
\hline$\Delta \mathrm{IP}$ & -0.017510 & 0.055405 & -0.316033 \\
\hline$\Delta \mathrm{GP}$ & 0.064120 & 0.059019 & 1.086428 \\
\hline$\Delta \mathrm{M} 2$ & $-1.24 \mathrm{E}-05$ & $1.61 \mathrm{E}-05$ & -0.768431 \\
\hline$\Delta \mathrm{GR}$ & 2.610381 & 4.300147 & 0.607045 \\
\hline$\Delta \mathrm{OP}$ & 0.047715 & 0.174533 & 0.273386 \\
\hline$\mu_{t-1}$ & -0.051107 & 0.027508 & -1.857890 \\
\hline
\end{tabular}

Significant at 5\% level, Lag selection (2) 